\title{
Effects of Concanavalin A on Cytokine mRNA Expression in Mouse Liver
}

\author{
Toshihiro Okamoto and Tadashi Kobayashi \\ Research Laboratories, Nippon Chemiphar Co., Ltd., I-22 Hikokawato, Misato, Saitama 341, Japan \\ Received June 26, 1997 Accepted August 9, 1997
}

\begin{abstract}
The effects of concanavalin A (Con A) on liver cytokine gene expression was studied in mice. The CD4 mRNA expression in normal liver suggests the presence of $\mathrm{CD} 4^{+} \mathrm{T}$ cells. The administration of Con A induced interleukin (IL)-13, IL-2 and IL-2 receptor mRNAs, which implies lymphocyte activation in the liver. Interferon- $\gamma$ and tumor necrosis factor- $\alpha$ mRNA expressions were increased gradually. The present results showed that Con $\mathrm{A}$ induced liver cytokine genes. This cytokine gene induction might have been the result of lymphocyte activation in the liver.
\end{abstract}

Keywords: Concanavalin A, Liver, Cytokine mRNA

Concanavalin A (Con A) is a plant lectin from jack beans known to mitogenically activate $T$ lymphocytes in vitro (1). Intravenous administration of Con A to mice induces $\mathrm{T}$ lymphocyte-dependent hepatic injury (1). Treatment with Con A releases cytokines into the serum of animals $(1,2)$. However, there has been no study on the effect of Con A on liver cytokine expression. Since cytokines act locally in many cases, the cytokine levels in the serum do not reflect the real activity in the liver. In the present study, we examined the effect of Con A on cytokine expression in the liver. We used the polymerase chain reaction (PCR) because this method is sensitive enough for identification of cytokines that are expressed at low levels.

Female BALB/c mice obtained from Charles River Japan, Inc. (Atsugi) were used at 7-10 weeks of age. The animals were kept in an air-conditioned room and given chow and water ad libitum. Con A was administered to mice $(0.2 \mathrm{mg} / \mathrm{mouse})$ via a tail vein. The sources of Con $A$ and dexamethasone (DEX) were Seikagaku Kogyo (Tokyo) and Wako Pure Chemical Industries, Ltd. (Osaka), respectively. Mice were anesthetized with ether before sampling. Blood was sampled from an abdominal vein for plasma analine aminotransferase (ALT) measurement (3) at $8.5 \mathrm{hr}$ after Con A treatment. The liver was sampled without perfusing it. Data were analyzed according to the test for equal variance and Welch's correction.

RNA isolation (4) and PCR analysis were performed as described previously (5). First strand cDNA was amplified by 30 cycles of denaturation at $94^{\circ} \mathrm{C}$ for $45 \mathrm{sec}$, annealing at $55^{\circ} \mathrm{C}$ for $45 \mathrm{sec}$ and extention at $72^{\circ} \mathrm{C}$ for $1.5 \mathrm{~min}$. The previously reported (5) specific primers for $\mathrm{CD} 4$, interleukin (IL)-1;, IL-2, interleukin-2 receptor (IL-2R), interferon (IFN)- $\gamma$, tumor necrosis factor (TNF)- $\alpha$, IL-6, transforming growth factor (TGF)- $\beta 1$ and glyceraldehyde3-phosphate dehydrogenase (GAPDH) were used.

Intravenous injection of Con A induced liver injury, as assessed by the serum transaminase level (ALT (U/L): $2681 \pm 1171$, compared with the non-treated level, $39 \pm 9$, mean \pm S.E., $n=6, P<0.01$ ). CD4 is a glycoprotein expressed on the helper $T$ cell surface (6). The expression of CD4 mRNA in normal liver suggests the presence of $\mathrm{CD}^{+} \mathrm{T}$ cells in the liver (Fig. 1). IL-1 $\beta$ facilitates the activation of T cells (7), and IL-2 and IL-2R are markers of $T$ cell activation $(7,8)$. At 60 and $120 \mathrm{~min}$ after Con A treatment, IL-1 $\beta$ mRNA was elevated, and IL-2 and IL2R mRNAs were induced (Fig. 2A). Since IL- $1 \beta$ primers amplified several bands, the presence of IL-1, $\$$ mRNA was ascertained by observing the size of the amplified product. The induction of those mRNAs in the liver suggests the activation of $\mathrm{T}$ cells at 60 and $120 \mathrm{~min}$ after Con A

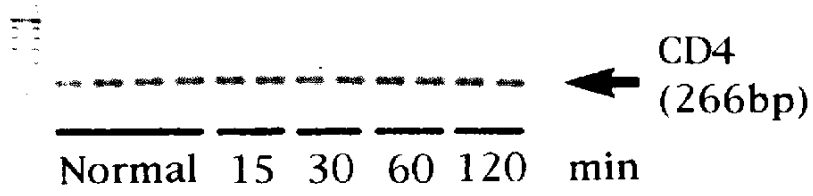

Fig. 1. PCR analysis of CD4 mRNA expression in the liver. Livers were removed at 15, 30,60 and 120 min after Con $A$ administration. RNA was isolated and its expression was measured by means of PCR. 


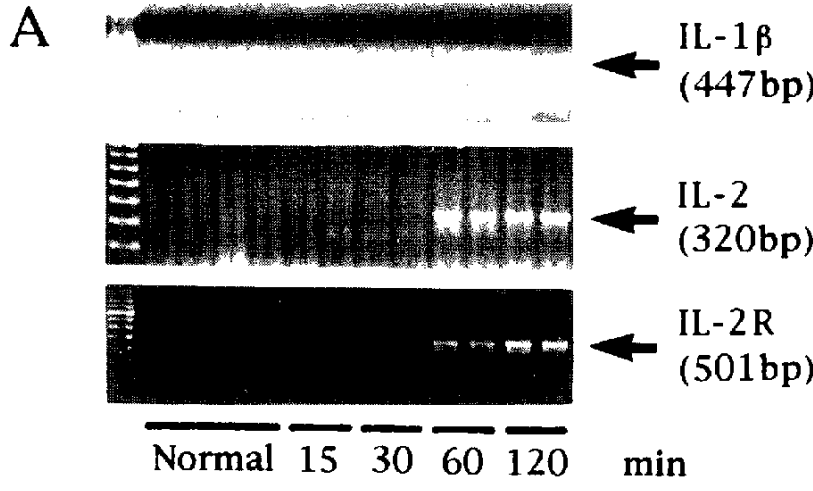

B

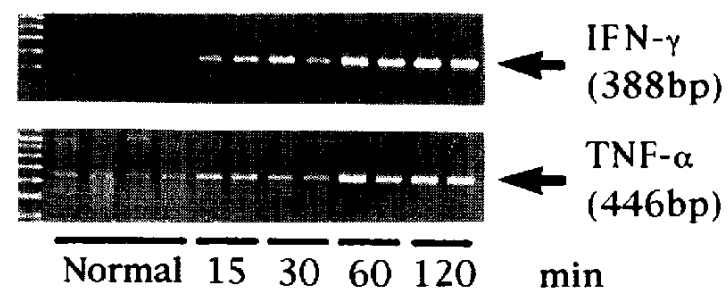

C

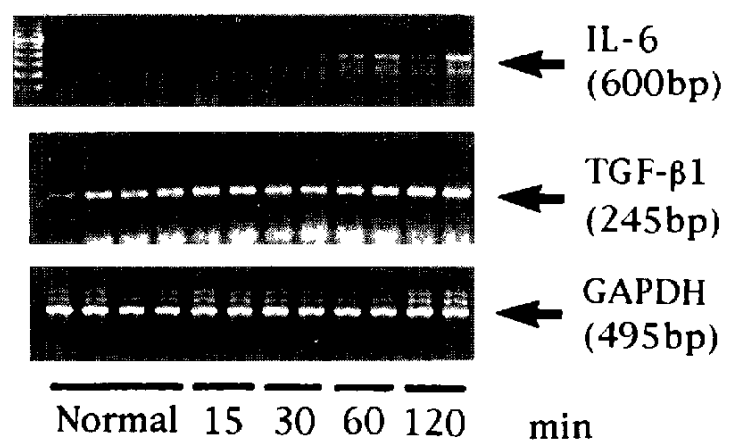

Fig. 2. $P C R$ analysis of cytokine gene expression in the liver. Livers were removed at 15,30,60 and $120 \mathrm{~min}$ after Con $\mathrm{A}$ administration. RNA was isolated and subjected to PCR amplification. A: Expression of IL-1 $\beta, 1 L-2$ and IL-2R mRNAs. B: Expression of IFN $-\gamma$ and TNF- $\alpha$ mRNAs. C: Expression of IL-6, TGF- $\beta 1$ and GAPDH mRNAs.

treatment. IFN $-\gamma$ and TNF- $\alpha$ are important mediators of liver injury in this model $(1,2)$. Con A induced IFN- $\gamma$ and TNF- $\alpha$ mRNAs gradually (Fig. 2B). Initial slight induction of IFN- $\gamma$ and TNF- $\alpha$ mRNAs at 15 and $30 \mathrm{~min}$ after Con $\mathrm{A}$ injection was followed by late strong induction of these mRNAs at 60 and 120 min (Fig. 2B). IFN- $\gamma$ and TNF- $\alpha$ are also produced upon T cell activation (8, 9). Furthermore, the late strong expressions of IFN- $\gamma$ and TNF- $\alpha$ mRNAs were induced along with those of IL-2 and IL-2R mRNAs. Thus, it is plausible that the late strong induction of IFN- $\gamma$ and TNF- $\alpha$ mRNAs might be a result of $\mathrm{T}$ cell activation. CD4 mRNA expression and the faint band of CD8 mRNA (not shown) suggest the contribution of $\mathrm{CD}^{+} \mathrm{T}$ cells to induce these cytokine

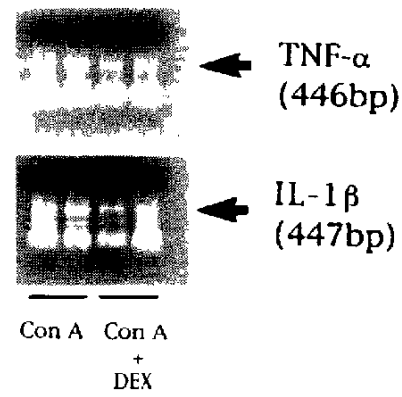

Fig. 3. Effects of DEX on cytokine gene expression. Livers were removed $60 \mathrm{~min}$ after Con A administration. RNA was isolated and subjected to PCR amplification. Pretreatment with DEX (2.5 $\mathrm{mg} / \mathrm{kg}$, i.p.) was performed at $1 \mathrm{hr}$ before Con A injection. The liver samples in the left two lanes were from two Con A-treated mice and those in the right two lanes from two Con A + DEX-treated mice. Top: TNF- $\alpha$ mRNA expression. Bottom: IL-1 $\beta$ mRNA expression.

mRNAs. However, further studies are needed to elucidate this possibility. The IL-6 mRNA expression shown here (Fig. 2C) indicates the contribution of this cytokine within the liver. TGF- $\beta 1$ mRNA, which has been reported to enhance liver extracellular matrix components (10), was constitutively expressed (Fig. 2C). The constant GAPDH mRNA expression showed that there was no marked tube to tube variation. Glucocorticoids suppress immune and inflammatory reactions by inhibiting cytokine expression (11). Pretreatment with DEX (2.5 $\mathrm{mg} / \mathrm{kg}$, i.p.) at $1 \mathrm{hr}$ before Con A treatment prevented Con A-induced hepatitis (ALT (U/L): Con A 960 \pm 109 , Con $A+D E X ~ 37 \pm 3, n=4, P<0.01)$. Moreover, the Con A-induced cytokine gene expression was inhibited by DEX (Fig. 3). Thus, cytokine induction may be related to the development of hepatitis in this model.

Taking all available results into account, we conclude that Con $\mathbf{A}$ administration induces cytokines in the liver, which might be the result of lymphocyte activation. The cytokine expression in the liver is closely related to the induction of hepatitis by Con $\mathrm{A}$.

\section{Acknowledgment}

We wish to thank Mr. Kaoru Hara for critically reading the manuscript.

\section{REFERENCES}

1 Gantner F, Leist M, Lohse AW, Germann PG and Tiegs G: Concanavalin A-induced T-cell-mediated hepatic injury in mice. The role of tumor necrosis factor. Hepatology 21, $190-198(1995)$

2 Mizuhara H, Uno M, Seki N, Yamashita M, Yamaoka M, Ogawa T, Kaneda K, Fujii T, Senoh $\mathrm{H}$ and Fujiwara H: Critical involvement of interferon gamma in the pathogenesis of $\mathrm{T}$-cell activation-associated hepatitis and regulatory mechanisms of interleukin-6 for the manifestation of hepatitis. Hepatology 23, 
1608-1615 (1996)

3 Karmen A, Wroblewski F and LaDue JS: Transaminase activity in human blood. J Clin Invest 34, 126-133 (1995)

4 Okamoto T, Mitsuhashi M, Fujita I, Sindhu RK and Kikkawa Y: Induction of cytochrome P450 1A1 and $1 \mathrm{~A} 2$ by hyperoxia. Biochem Biophys Res Commun 197, 878-885 (1993)

5 Okamoto T, Furuya M, Yamakawa T, Yamamura K-I and Hino O: TNF- $\alpha$ gene expression in the liver of the IFN- $\gamma$ transgenic mouse with chronic active hepatitis. Biochem Biophys Res Commun 226, 762-768 (1996)

6 Littman DR and Gettner SN: Unusual intron in the immunoglobulin domain of a newly isolated murine CD4(L3T4) gene. Nature 325, 453-455 (1987)

7 Dinarello CA: Biology of interleukin 1. FASEB J 2, 108-115
(1988)

8 Paul WE and Seder RA: Lymphocyte response and cytokines. Cell 76, 241-251 (1994)

9 Tocci MJ, Matkovich DA, Collier KA, Kwok P, Dumont F, Lin S, Degudicibus S, Siekierka JJ, Chin J and Hutchinson NI: The immunosuppressant FK506 selectively inhibits expression of early $T$ cell activation genes. J Immunol 143, 718-726 (1989)

10 Weiner FR, Giambrone MA, Czaja M, Shah A, Annoni G, Takahashi T, Eghbali $\mathrm{M}$ and Zern MA: Ito-cell gene expression and collagen regulation. Hepatology 11, $111-117$ (1990)

11 Auphan N, DiDonato JA, Rosette C, Helmberg A and Karin M: Immunosuppression by glycocorticoids: inhibition of NF$\kappa$ B synthesis. Science 270, 286-290 (1995) 